\title{
Mental Intelligence and the Complexity of Sentence Structures in the Interaction between Teachers and Children with Autism
}

\author{
Djatmika $^{1}$, Ahfi Hikmawati ${ }^{2}$, Sumarlam³ \\ ${ }^{1}$ Universitas Sebelas Maret, Indonesia.e-mail: djatmika@staff.uns.ac.id \\ 2Universitas Sebelas Maret, Indonesia.e-mail:ahfihikmawation@gmail.com \\ 3 Universitas Sebelas Maret, Indonesia.e-mail:sumarlam@staff.uns.ac.id
}

\begin{tabular}{ll}
\hline ARTICLE INFO & ABSTRACT \\
\hline $\begin{array}{l}\text { Keywords: } \\
\text { children with autism, } \\
\text { complexity of sentence } \\
\text { structure, mental } \\
\text { intelligence, teachers }\end{array}$ & $\begin{array}{l}\text { of children with autism and their capability in understanding the } \\
\text { com their teachers. In addition, this study also explains the complexity } \\
\text { of the sentence structure produced by the autistic children in } \\
\text { interacting with the teachers. The data of this research are in the form } \\
\text { of sentence structures used in the class interaction between teachers } \\
\text { and students with autism. The collected data were then analyzed by } \\
\text { classifying the sentences used by the teachers and the sentences } \\
\text { produced by children with autism. The results showed that children } \\
\text { with high mental intelligence were able to understand the complex } \\
\text { sentence structures used by the teachers and were able to respond and } \\
\text { speak utterances in the form of complex sentences. This shows that } \\
\text { children with high mental intelligence understand and can produce } \\
\text { sentences in a complex structure better than those with a low mental } \\
\text { one. }\end{array}$ \\
$\begin{array}{l}\text { DOI: } \\
\text { http://dx.doi.org/10.21093 }\end{array}$ \\
lijeltal.v5i2.641
\end{tabular}

\section{Introduction}

Recently, the Indonesia Ministry of Education and Culture (MOEC) has decided to implement a Computer-based national examination (CBNE) to some eligible secondary schools, according to the website of the MOEC (2019). The government believes that implementing this kind of assessment will improve the national examination integrity index by the intervention of information and communication technology in its national examination. However, the administration of CBNE spends more time than paper-based tests spending 
three days, which may lead to the validity issue of CBTNE (Hapli, Kristiyono, \& Alamsyah, 2017).

The process of assisting and teaching children with autism requires effective strategies. This is related to the fact that, in general, such exceptional children have problems in communication (see Wenar, 2004; Rahayu, 2014). The communication barriers appear to affect several other aspects of development (Toth et.al., 2006; Chodidjah \& Kusumasari, 2018). It is further explained by Safaria (2005) that the common characteristic children with autism show, among others, is the inability to interact verbally with other people. The other experts suggest that children with this condition tend to imitate what other people say (Schuler \& Fletcher, 2003) without considering whether other people follow the conversation or not (Shulman, 2003). Moreover, wrong exploitation of pronouns, and less skilled in carrying out interactions are often performed by the children (Asrizal, 2016).

The conditions of children with autism are various, including children who only suffer autism and those who are with autism as well as with language impairment. A research conducted by McConnel shows that children with autism without language impairments are able to produce complex sentences like normal children of the same age (McConnel, 2010), although on the other hand, the ability of children with autism to understand sentences, including complex sentences, is problematic (Kover, et.al., 2014). In connection with this condition, the assistants and teachers of children with autism must have competence in several modes of teaching, namely verbal aspects, non-verbal and paralinguistic aspects, as well as properties to support the parenting and learning process for children with autism. Furthermore, for verbal expressions, teachers need to consider the grammatical quality of sentences that are realized in the utterances used in presenting teaching materials to children with autism.

In addition, in using sentences with a certain level of complexity, teachers need to consider the level of intelligence of children. Azwar (2004) quotes David Wechsler as saying that intelligence is one of the internal factors that affect children's achievement, and this intelligence is referred to as the collection or totality of a person's ability to act with certain goals, think rationally and face their environment effectively.

A research by Hirosawa et.al., (2020) has shown a relationship between the intelligence level of autistic children and their social cognitive abilities. They claimed that the better the intellectual quality of a child with autism, the easier it will be for him to understand expressions that are packaged in complex sentences. Another study has examined the relationship between the importance of sentence complexity to these autistic children. Krantz et.al. (1981) stated that complex sentences are not only considered part of the teacher's language, but also need to be taught to children. Krantz and his research team conducted three debriefing experiments for children with autism with the ability to use complex sentences. Research conducted by this team shows that children with autism are able to master sentences with complex and complex constructs - constructs that will support them in their daily social interactions.

In connection with the above phenomena, this article discusses the intelligence of children with autism and the ability to understand and produce complex sentences. As is known, from the verbal side of linguistics, the intelligence of verbal autistic children is different. Children with a high level of intelligence will easily understand the teacher's speech which is packaged in complex sentences. Children with this quality of intelligence also tend to be able to produce 
speech with more complex sentence construction. Thus, teachers need to understand and consider this condition so that the learning process they carry out can run effectively in relation to the grammatical quality of the sentences spoken in the classroom.

\section{Literature Review}

\subsection{Mental Intelegensi}

Howard Gardner introduces a theory of multiple intelligence or multiple intelligence. Gardner mentions that there are eight kinds of multiple intelligences, namely language, logicmathematics, musical, bodily-kinesthetic, spatial, naturalist, interpersonal, and intrapersonal. Then, in 2009, Gardner added two more types of intelligence, namely existential and moral. The following is an illustration figure of Gardner's multiple intelligences (Hoerr, Thomas R translated by Nilandari, 2007: 15).

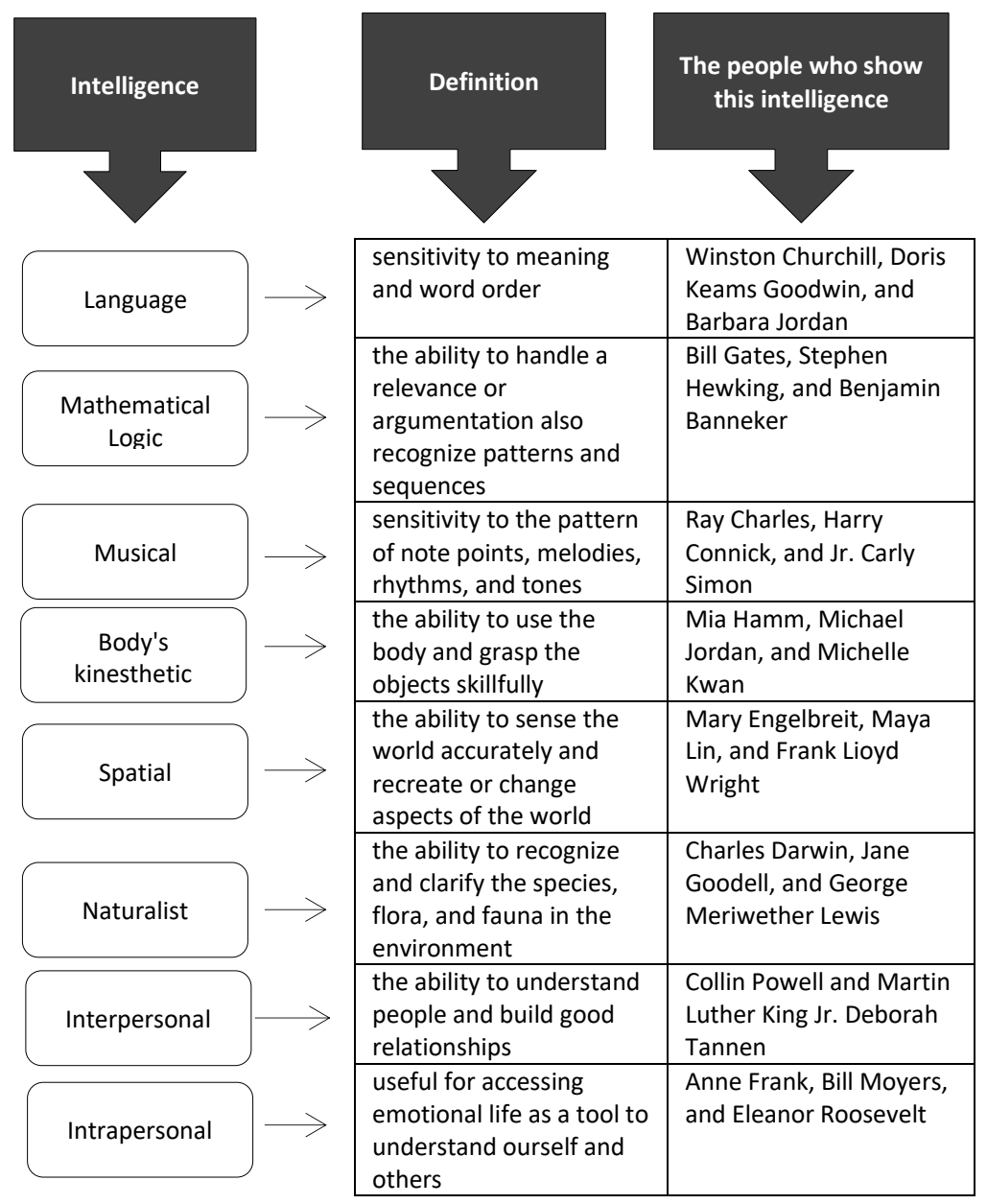

Figure. Gardner's multiple intelligences

\subsection{The Complexity of Sentence Structures}

Sentences in syntactic studies are divided into two, namely simple and compound sentences. The former is synonymous with singular-meaning that the sentence just has one clause, whereas the later is represented by a sentence consisting of more than one clause. An example of a simple sentence that has the construction of one subject + predicate as a verb is Joko makan nasi "Joko eat rice". A simple sentence that has the construction of one pair of 
subject + predicate as a noun, namely Joko guru SMP "Joko is a senior school teacher". A simple sentence that has the construction of one subject + predicate as an adverb, namely Joko selalu tergesa-gesa "Joko is always in a hurry". A simple sentence that has the construction of one subject + predicate as an adjective, namely Joko ganteng "Joko is handsome".

Sentences consisting of two or more clauses are called compound sentences. Based on the division, it is divided into coordinating and subordinating compound sentences. The former is a sentence consisting of one clause that is not part of another. Put in other words, the clauses in the sentence are all independent of each other. Such a construction is then supported by coordinating conjunctions like tapi "but", dan "and", sehingga "so", and atau "or". Meanwhile, the other type of construction position one clause as part of another, so that one clause dependent to the other (independent) clause. Clauses that are part of other clauses are called subordinate clauses, while other clauses are called main ones. The sentence of Aku mengerti bahwa belajar bahasa Inggris itu sangat penting "I understand that learning English is very important" is an example of this subordinating construction.

\title{
3. Research Methodology
}

\subsection{Research Subjects}

The subjects of this study were children with autism and their class teachers. The data of this research are utterances produced by the teachers as well as the children in their class interaction. The analysis of these data was performed to see the mental intelligence related to the sentence structures.

\subsection{Instruments}

The provision of data in this study was carried out by doing observation, listening technique, and note-taking technique. In terms of recording, this study used orthographic transcription.

\subsection{Data Analysis Procedures}

The data analysis method used in this study is the orthographic equivalent method. The analysis technique used is the comparative differentiating technique to relate the mental intelligence and the complexity of the sentence structure. The data were then analyzed to see how mental intelligence has a role in understanding and producing complex sentence structures performed by children with autism.

\section{Findings}

\subsection{Teachers' Utterances Representing Simple Sentence Construction}

\author{
Interaction 1 \\ Teacher : Selamat pagi Alanis "Good morning Alanis" \\ Selamat pagi Alanis"Good morning Alanis" \\ Alanis : Pagi bu "Morning miss"
}

The teacher utterance in the interaction is in the form of a simple sentence that greeted Alanis when she was about to start learning. Alanis was able to respond to the greeting by executing another greeting for her teacher. Her utterance represents a simple sentence. This means that Alanis is able to respond to the teacher's utterance in the form of simple with another utterance in simple construction as well. Interaction 1 above shows that Alanis' 
mental intelligence is good because she already has a sensitivity to the meaning of an utterance in simple sentence construction.

Interaction 2

Teacher : Apa kabar? "How are you?"

Fikri : Baik "Fine"

The interaction above starts as the teacher greets Fikri and asks about his condition. Her greeting utterance represents a simple sentence construction. In responding to such a greeting, the student executes another utterance representing an elliptic sentence of which its complete construction is also simple. Similar to the previous student, Fikri in Interaction 2 also shows his inteligence quality of being good in understanding simple sentence uttered by his teacher, and he is also able to utter another simple construction utterance for his teacher.

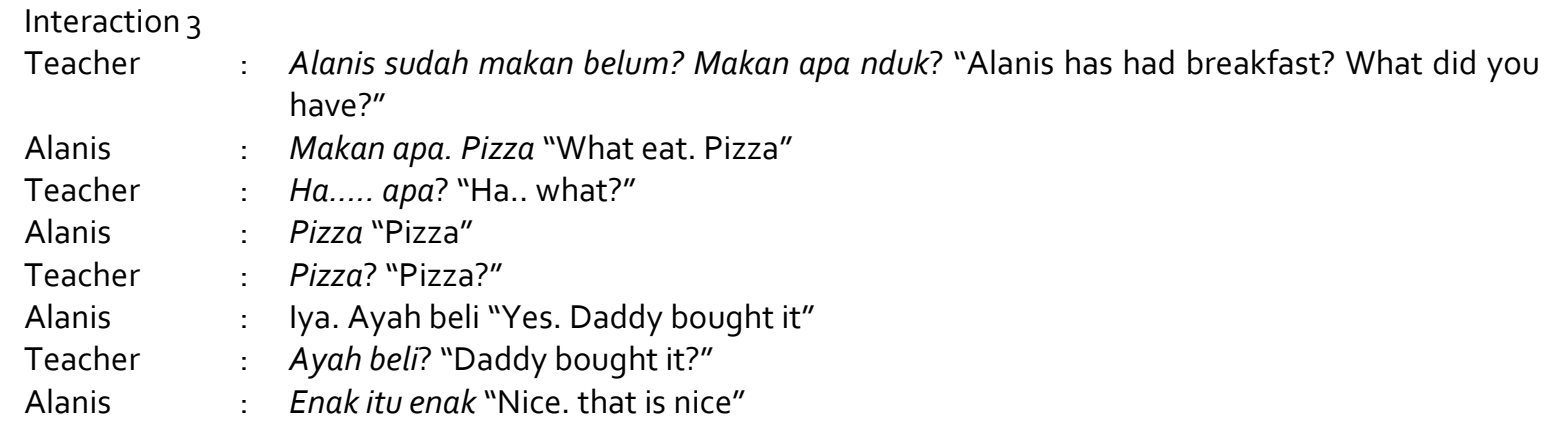

This is an apperception performed by the teacher to ask about the condition of the kid who had breakfast or not on that day. Alanis, the student is able to respond to every initiating utterance which represents simple sentence construction fom her teacher. There are two types of construction used by the teacher, i.e. simple sentence and elliptic construction of which all represent simple sentences. Similarly, the student also has good quality in understanding the teacher's utterances, so that she can provide responses in the forms of utterances representing simple sentence construction.

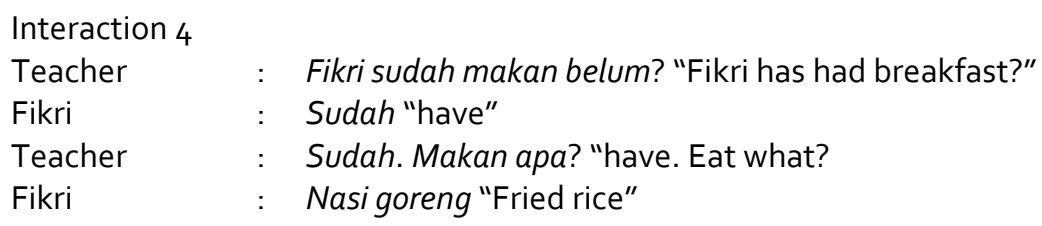

The teacher's speech on the four interaction data is in the form of a simple sentence asking Fikri whether she has eaten before the lesson begins. Fikri was able to respond by saying yes and fried rice. Fikri's speech shows that he has eaten. Eating fried rice. The form of Fikri's speech when answering Mrs. Novi's question was a simple sentence (ellipsis). This means that Fikri is able to respond to Mrs. Novi's speech from simple sentences and responds with simple sentences as well. Based on the four interaction data, it shows that Fikri's mental integrity is good because it has a sensitivity to the meaning of speech and sentence structure in response to a speech. 


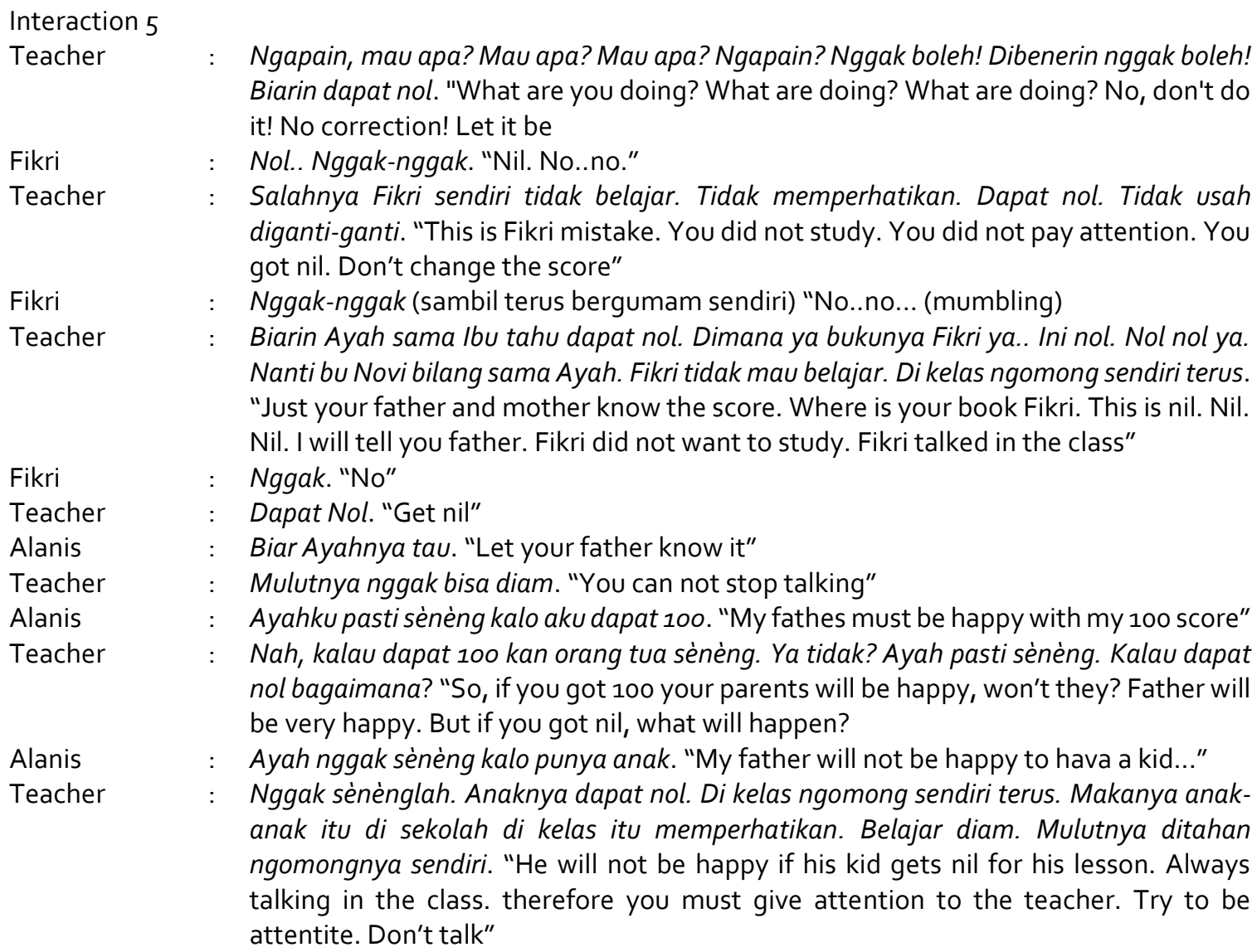

The above interaction occurs between a teacher and two students with autism. All teacher utterances are carried out in simple sentence constructs. Likewise, the two students who were involved in the interaction also used utterances formed in simple sentence construction - some of the utterances were in the form of ellipses. Although all utterances are in the form of simple sentence constructions, the teacher often uses multiple utterances in one turn. In other words, the teacher uses a turn to send more than one message by executing several utterances in one, for example in: Ngapain, mau apa? Mau apa? Mau apa? Ngapain? Nggak boleh! Dibenerin nggak boleh! Biarin dapat nol "What are you doing? What are doing? What are doing? No, don't do it! No correction! Let it be" This kind of configuration is actually not very good for students, because a large number of messages in one turn is of course more difficult to understand. This is indicated by the attitude of the student who does not care about the teacher's speech, and he still does actions that are prohibited by the teacher. The same case happens to the last turn performed by the teacher in which she executes several utterances to one of the students in the class.

Interaction 6

Teacher

Fikri

Teacher

Fikri

Teacher

Fikri
Masih ingat tidak ya? Kemarin kita belajar hewan peliharaan. Apa saja contohnya hewan peliharaan? Fikri (sambil menunjuk ke arah Fikri) "somebody remembers? We learned about pet yesterday. So can you mention a pet? Fikri ( the teacher is pointing Fikri)

\section{Gajah. "Elephant"}

Hewan peliharaan. Apa Alanis? (sambil menunjuk ke arah Alanis) "A pet. Alanis?"

Gajah. "Elephant"

Ayo, hewan peliharaan. "Come on, a pet"

Sapi. "Cow" 
The teacher asked Fikri about the material that was learned the day before. The interaction above took place when the teacher was about to shift to another material, that was about pets. She asked Fikri to mention a name of pet which was responded with gajah "elephant". The teacher produced an utterance representing simple sentence construction, while Fikri, the student, used an elliptic sentence for his utterance. Even though, the answer is not really correct, the student's response to the teacher's question might indicate that he understood what the teacher asked---he, unfortunately- did not remember the names of pets exposed by the teacher the day before.

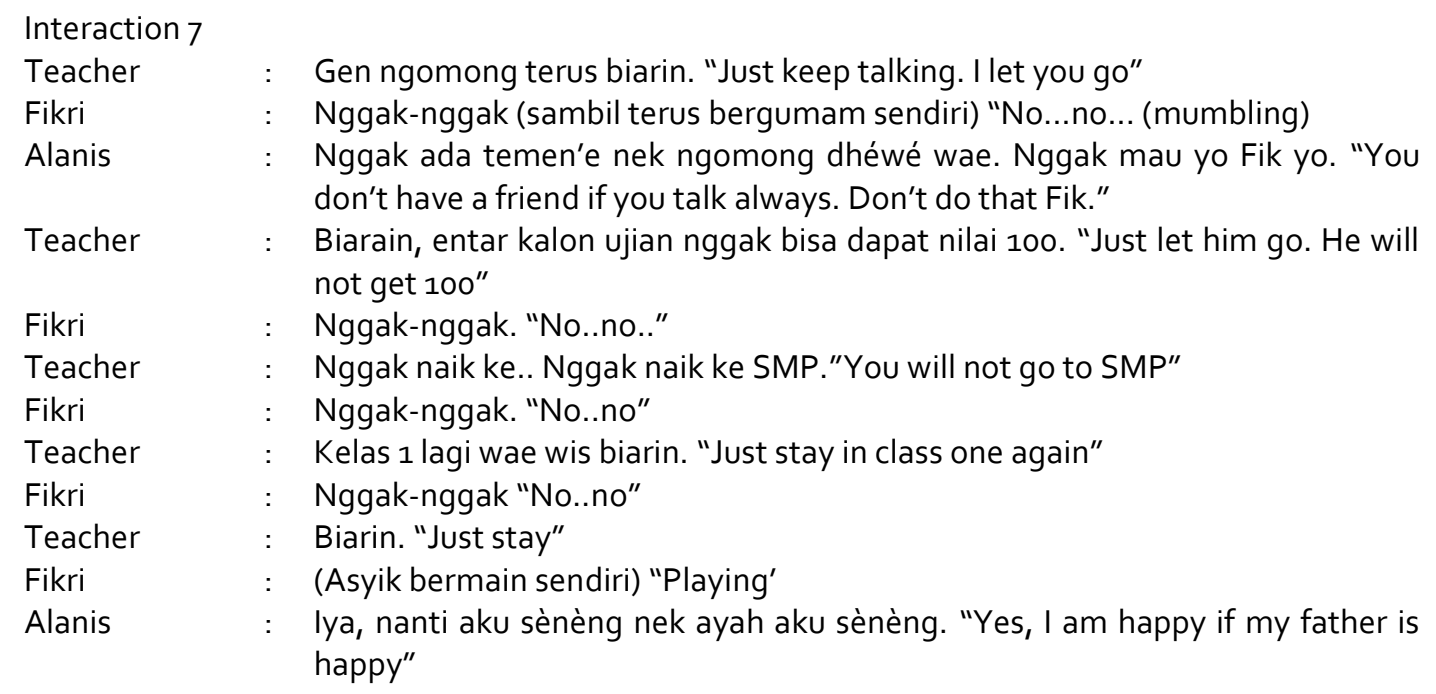

Interaction 7 shows that the teacher was not happy with one of the students who always talked in the class. She warned him several times, but the student did not care of the warnings. In addition, the teacher also told the student what would happen if he did not listen to the teacher's advice. Utterances represented simple sentences were produced by the teacher in a warning and telling the student. The strategy in using such a sentence construction seems to be effective as the student might understand the messages behind the utterances, as shown by his responses to the warning and telling. However, although Fikri, the student, understood the utterances performed by his teacher, his intelligence quality limits him in responding using complete construction. He refused the warning and the telling just by saying Nggak meaning No. On the other hand, another student, Alanis, showed much better intelligence in which she contributed an utterance representing a complex sentence structure in joining the interaction taking place between the teacher and Fikri.

\subsection{Teachers' Utterances Representing Compound Sentence Construction}

The following learning process interactions show that sometimes the teacher contributes utterances that represent compound or/ and sentence construction. In addition, the students also, in a certain part of the learning process, performed similar construction for their utterances. Such construction for the utterances has an impact on the students due to their intelligence quality. One interaction accommodating utterances with such quality is presented as follows. 


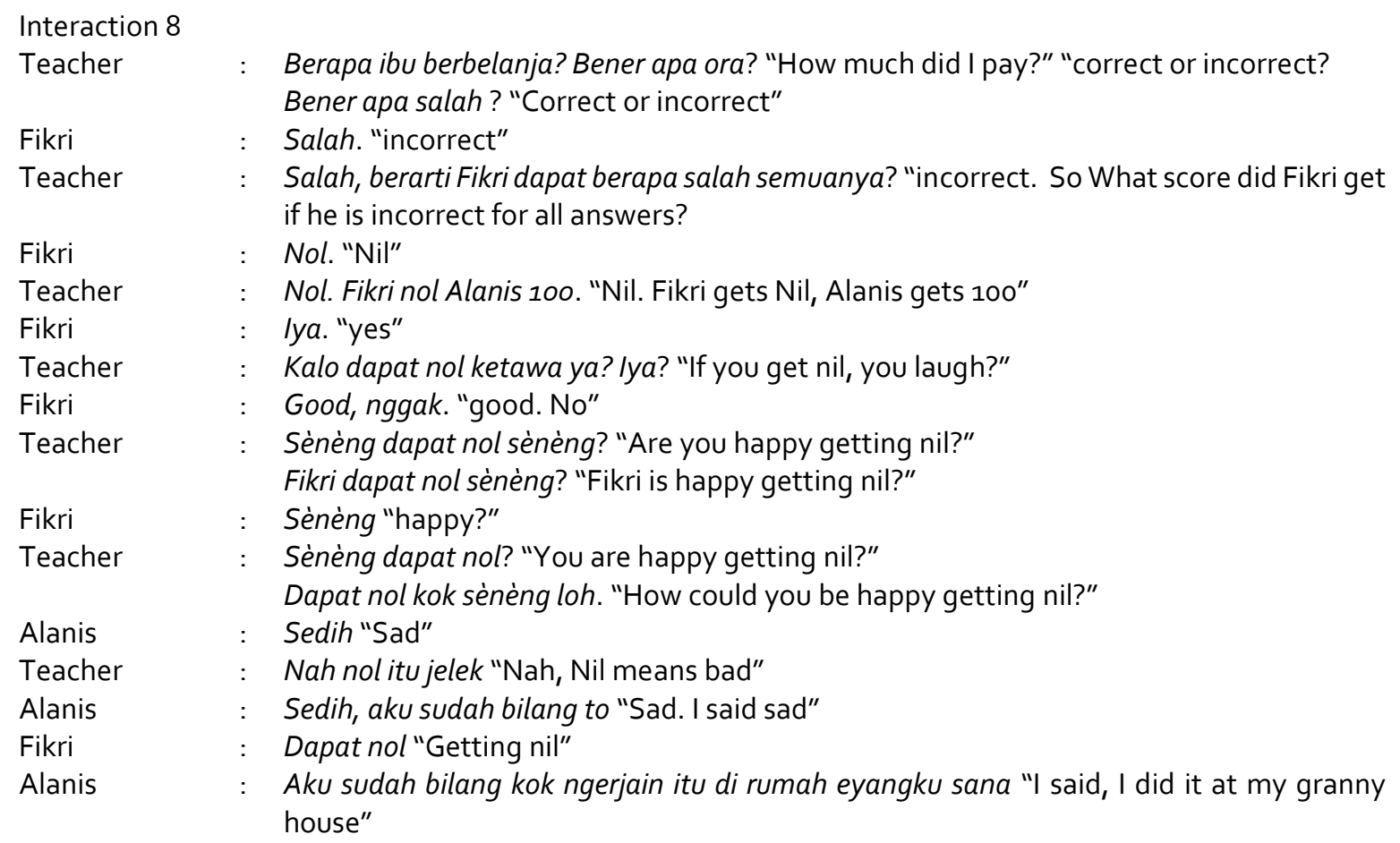

Several utterances performed by the teacher in the interaction above represent bad sentence construction. Even though, she intends to produce a simple sentence for such utterances. The words arrangement in the construction seem not to have good Indonesian grammar quality so two of them are produced in elliptic form such as Nol? "Nil"; Seneng?"Happy?". In addition, two utterances are produced based on complex sentence structures such as Berarti Fikri dapat berapa salah semuanya? "So What score did Fikri get if he is incorrect for all answers?"; Fikri nol Alanis 100 "Fikri gets Nil, Alanis gets 100"; Kalo dapat nol ketawa ya? "If you get nil, you laugh?". These three sentences are in complex construction, and two of them have grammar problems as each misses a grammar element in it, namely conjunction. For the student, utterances represented complex construction might be more difficult to understand, yet Fikri's response to these utterances is relevant, meaning that he understood what the teacher said with the utterances. However, in another case, the complicated utterance might give problems to the student to get the messages as shown in the following dialog

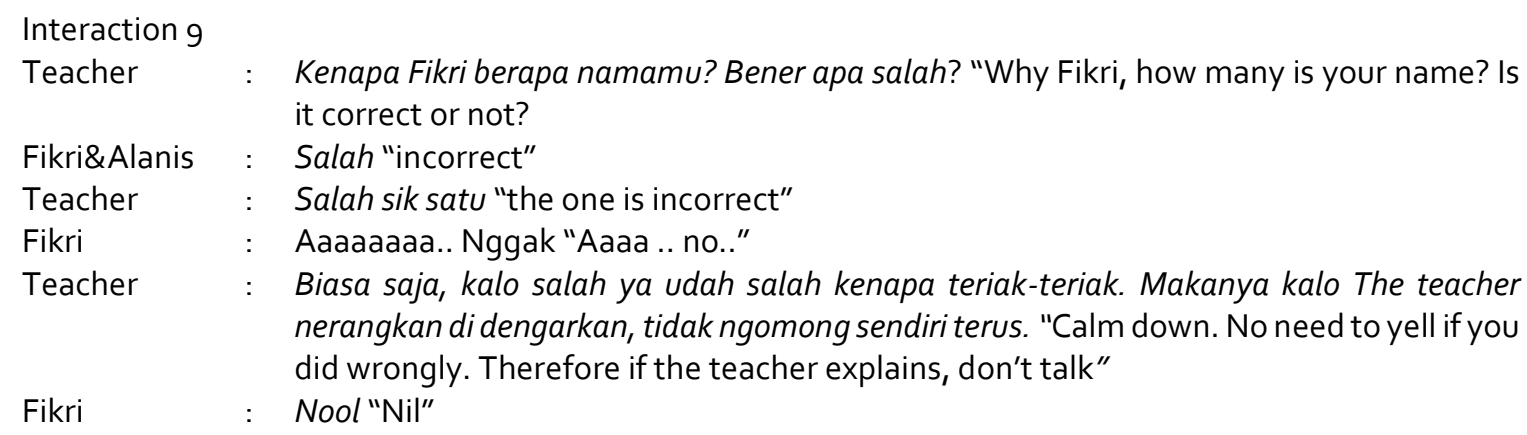

The interaction above took place in the session in which the teacher checked the homework performed by the students. When she found an incorrect answer-and she told the 
incorrectness to the student who did it, Fikri, the student expressed regret by saying "Aaaaa, nggak "Aaaaa,No." The teacher told him no to react like that. She told him that he deserved the result as he always talked in the class and never gave attention to the teacher in the learning process. In this interaction, the teacher has utterances represented complex sentence structure as "Biasa saja, kalo salah ya udah salah kenapa teriak-teriak. "Calm down. No need to yell if you did wrongly.", and Makanya kalo The teacher nerangkan di dengarkan, tidak ngomong sendiri terus. "Therefore, if the teacher explains, don't talk." Such a grammar quality tends to be more problematic for the students to understand-even though the response he gave does not really show whether he understood his teacher's utterances or not as he only said Nool "Nil".

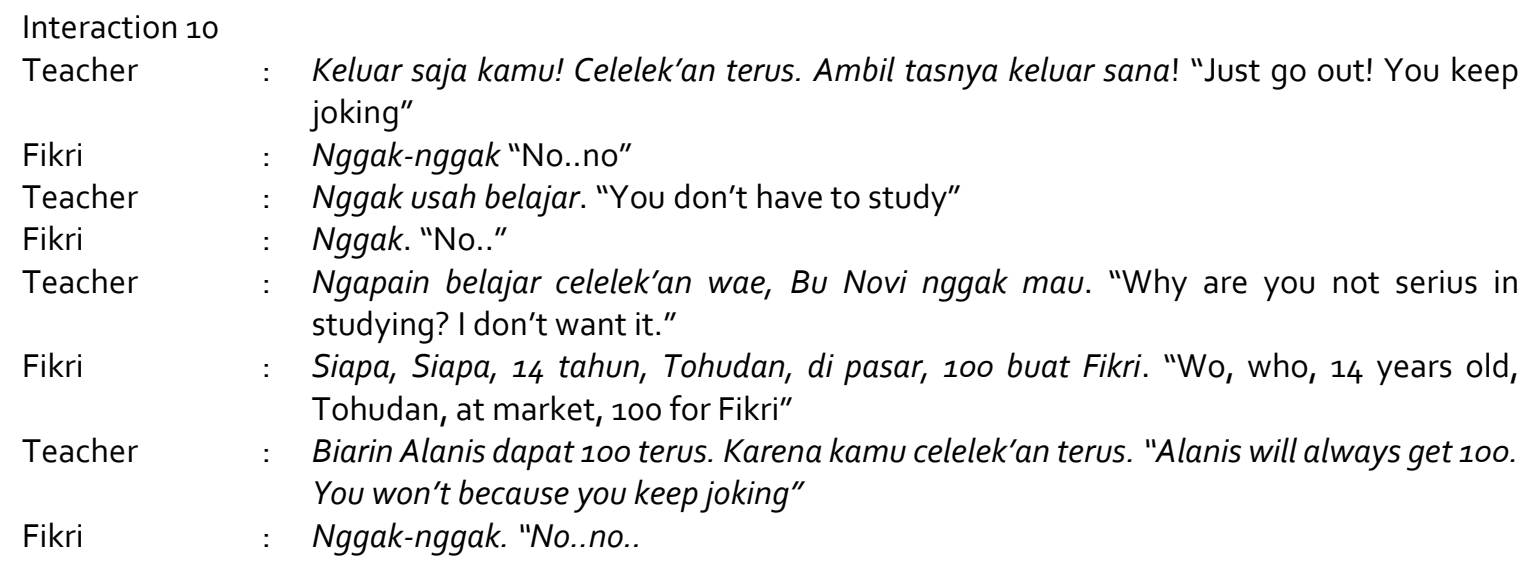

In the interaction above, the teacher gives a warning several times to Fikri, one of the students in the class, as he keeps talking and playing. Even the teacher tries to send him out of the class as he does not listen to what the teacher is saying. The teacher also gives comments to Fikri as a student who keeps joking. She compares him with Alanis, another student, who is more serious in the learning process. To do the comparison, the teacher executes utterances representing complex sentence structure Biarin Alanis dapat 100 terus. Karena kamu celelek'an terus. "Alanis will always get 100. You won't because you keep joking". Fikri responds to the comment by denying in a short utterance Nggak..nggak."No...no" which is an elliptic form of a simple sentence of Aku nggak mau "I don't want". As such a response seems relevant to the initiating utterances performed by the teacher, then it indicates that Fikri understands the messages accommodated by complex sentence construction executed in her utterances. However, he seems not to be able to contribute the respond in an utterance representing complex sentence construction. The same case happens to Alanis, a girl in the class, as shown in the following interaction.

$\begin{array}{lll}\begin{array}{l}\text { Interaction } 11 \\ \text { Teacher }\end{array} & : \begin{array}{l}\text { Selamat pagi Alanis "Good morning, Alanis" } \\ \text { Selamat pagi Alanis"Good morning, Alanis" }\end{array} \\ \text { Alanis } & : \begin{array}{l}\text { Pagibu "Good morning Miss" } \\ \text { Teacher }\end{array} & \begin{array}{l}\text { Jawab yang baik ya, anak-anak itu bisa bicara, mulutnya di tutup. Ayo mulutnya } \\ \text { ditutup kalau menguap mulut di tutup. Alanis "Respon well, will you? Children can }\end{array} \\ & \begin{array}{l}\text { speak. Shut you mouth. Come on shut up your mouth when yawning. Alanis" } \\ \text { Alanis }\end{array} & \text { Ya "Yes" }\end{array}$


The conversation between the teacher and Alanis above shows the capability of such a student in understanding the utterances performed by the teacher. The context of the interaction is similar to the previous one, as the teacher feels upset because of the students' behavior. She gives several upsetting utterances which are designed in complex sentence structure like Jawab yang baik ya, anak-anak itu bisa bicara, mulutnya di tutup. Ayo mulutnya ditutup kalau menguap mulut di tutup. Alanis "Respon well, will you? Children can speak. Shut your mouth. Come on, shut up your mouth when yawning. Alanis". In one turn, the teacher has five messages, of which the last two are constructed in a complex sentence. Alanis gives a relevant response to her utterances-this indicates that she seems to be able to catch the messages of the utterances in turn, although she only contributes an elliptic construction $\mathrm{Ya}$ "Yes".

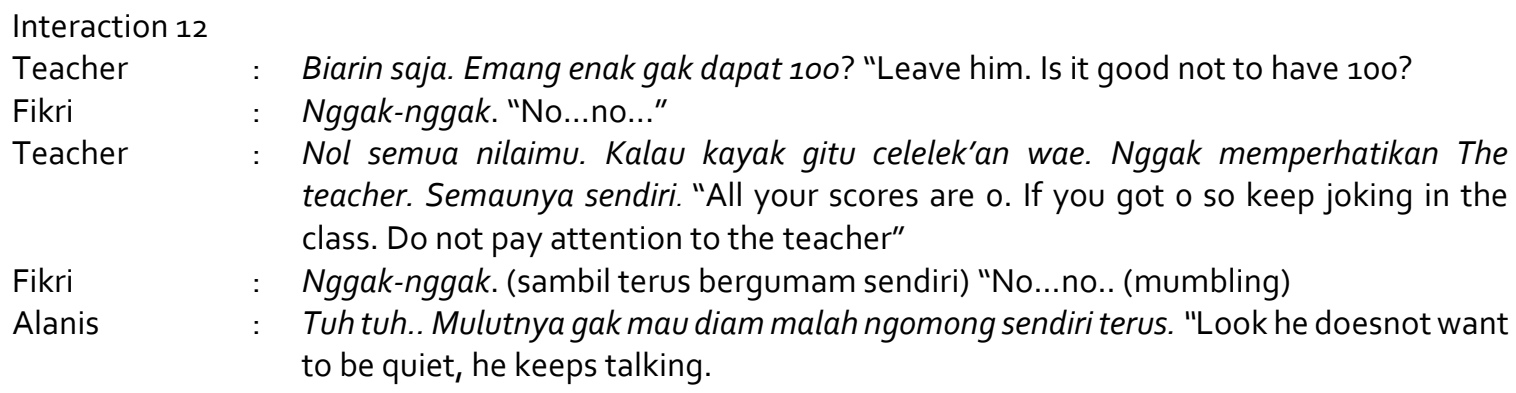

The interaction happened when the teacher checked and discussed the results of the homework done by the students. A girl named Alanis, got a 100 score as she did the best. All the answers were correct, whereas Fikri's performance was not satisfying. He answered all the questions wrong. Therefore, he got o for his score. He seems not to accept the score and wanted to reject it. The teacher gave a warning to him, telling him that he did not behave well. She said that he deserved the score as he was always not serious in the class. He kept talking and playing. The teacher had a turn consisting of several utterances, which are constructed in a simple and complex sentence as in Nol semua nilaimu. Kalau kayak gitu celelek'an wae. Nggak memperhatikan The teacher. Semaunya sendiri. ".All your scores are o. If you got o so keep joking in the class. Do not pay attention to the teacher." Of four utterances performed by the teacher in one of her turn, she has one which represents complex sentence structure, i.e kalau kayak gitu celekan wae." If you got o so keep joking in the class. The two children in the class responded to their teacher's multiple utterances in different quality. Fikri just said Nggak meaning No to deny what his teacher told, whereas Alanis, another child, responded to her teacher by executing utterances represented complex sentence structure. Both of the students seem to understand what their teacher said as their responses were relevant to the utterances in the initiating turn. However, as Alanis could contribute the response in complex sentence structure, while the other student, Fikri, just provided the one in an elliptic construction, then such a grammar quality might indicate that Alanis has better mental intelligence than Fikri.

\section{Discussion}

The interactions between the teacher and children with austim in the learning process above might present a kind of pattern representing the relation between the mental intelligence of children with autism and the quality of grammar, especially the complexity of sentence structure. The relation is represented in two areas-the children's understanding and 
production. The former is indicated by their responses towards complex utterances performed by the teacher. For this matter, both of the subjects in this research show a similar quality of mental intelligence. Both of them understand what their teacher tells or says. They provide every initiating utterance from the teacher with a relevant response such as in denying, answering, rejecting, and so on. Meanwhile, the children show different mental intelligence for the production. Alanis seems to have better mental intelligence as she can give several responses in complex sentence structure, while the other student, Fikri, tends to produce utterances in simple sentence construction of which some of them are constructed in short elliptic expressions. The pattern for the relationship between the mental quality and complexity of setence construction is displayed in the following table.

Table 2: The pattern for the relationship between the mental quality and complexity of setence construction

\begin{tabular}{|c|c|c|c|c|c|c|}
\hline $\begin{array}{c}\text { Teacher's Sentence } \\
\text { Construction }\end{array}$ & Subjects & $\begin{array}{c}\text { Students's Responding } \\
\text { Utterances }\end{array}$ & $\Sigma$ & $\begin{array}{c}\text { Menta } \\
\text { high }\end{array}$ & $\begin{array}{l}\text { gence } \\
\text { low }\end{array}$ & $\Sigma$ \\
\hline \multirow{3}{*}{$\begin{array}{l}\text { Utterances in Simple } \\
\text { Sentence }\end{array}$} & \multirow{2}{*}{ Alanis } & in simple sentence & 10 & \multirow{2}{*}{$\sqrt{ }$} & \multirow{5}{*}{$\sqrt{ }$} & 10 \\
\hline & & in complex sentence & 3 & & & 3 \\
\hline & Fikri & $\begin{array}{l}\text { in simple sentence } \\
\text { in complex sentence }\end{array}$ & $\begin{array}{l}11 \\
-\end{array}$ & \multirow{5}{*}{$\sqrt{ }$} & & $\begin{array}{l}11 \\
-\end{array}$ \\
\hline \multirow{4}{*}{$\begin{array}{l}\text { Utterances in Complex } \\
\text { Sentence }\end{array}$} & \multirow{2}{*}{ Alanis } & in simple sentence & 2 & & & 2 \\
\hline & & in complex sentence & 1 & & & - \\
\hline & \multirow{2}{*}{ Fikri } & in simple sentence & 2 & & \multirow{2}{*}{$\sqrt{ }$} & 2 \\
\hline & & in complex sentence & - & & & - \\
\hline
\end{tabular}

The table above shows that the children mental intelligence affects the complexity of sentences they use for their utterances. When the teacher speaks in simple sentence structure, Alanis can respond to her both by using utterances either in simple or in complex structure. Furthermore, she also can respond to her teacher's initiating complex utterance either in simple or in complex utterances. On the other hand, the other student, Fikri can only respond to all his teacher's utterances in simple utterances. He can not produce utterances in complex sentence structure.

The results presented above indicate a pattern of relationship between the intelligence level of autistic children and their verbal abilities. These findings support what Hirosawa et.al. (2020) suggested regarding high intelligence associated with better social cognition of children with autism which is also suggested by Hikmawati et. al. (2019) and by Djatmika et.al. (2020). The children verbal ability in this study is associated with the ability to understand and express complext sentences by their teacher and those produced by themselves. The focus of the results of this study is somewhat different from the study conducted by Malmjaars et.al. (2012) who related the receptive and productive abilities of autistic children with their profile and characteristics, and not their intelligence level. Meanwhile, the results of this study strongly support the findings presented by McConnell (2010) who claimed that a child only having autistic without language impairment conditions will be able to produce sentences with a high level of complexity compared to children with autism who also have language impairment or with mental disabilities. This shows that the condition of autism without innate mental disability represents a better level of intelligence, and this level of intelligence can affect the ability to produce sentences with these grammatical qualities. Furthermore, McConnell's research (2010) and the results of this study 
are also in line with what Kover et.al. (2014) suggested about the ability of children with autism to understand sentences.

Based on the findings above, teachers need to consider the level of intelligence of autistic students in preparing their teaching strategies. Of course, the lower the intelligence level of students with autistic conditions will require more detailed material preparation and teaching strategies. Several kinds of teaching methods have been presented by several previous researchers, such as Ivony \& Desmawati (2018) which showed the use of Behavioral Intervention strategies in learning materials, including language skills materials; Taryadi \& Kurniawan (2017) who used images as a stimulant to improve communication skills of autistic students; Puspitaningtyas \& Pratiwi (2018) who proved the increase in the verbal ability of children with autism after participating in several learning processes that applied floor time strategies. Meanwhile, the results of a study on the ability of children with autism to master the skills of using complex sentences were presented by Krantz et.al (1981) with three experiments using some grammatical elements to build sentences with complicated constraints. These results are in line with the findings of this study, especially those related to the correlation between the ability of children with autism to produce complex sentences and their level of intelligence. From some of the results of this study, it can be stated here that the level of intelligence of children with autism does have a role in the process of improving their verbal skills, but more than that teaching strategies must be considered to get better improvement results.

\section{Conclusion}

The results of the study suggest that mental intelligence of children with autism has a role in their language production. The higher the intelligence they have, the better language they produce. These findings might become input for teachers of children with autism to always consider the quality of mental intelligence their students have. The teachers should then adjust the quality of complexity for their utterances to the mental quality of their students so that the learning process can go conveniently for the children as they will be capable of following the class. In addition, the teacher should still consider various strategies in stimulating children with autism to increase their verbal competence for daily social interaction. In association with this fact, then it is recommended for other researchers to study the correlation between various teaching strategies and the capability of children with autism in producing complex construction of sentences.

\section{References}

Asrizal. (2016). Penanganan anak autis dalam interaksi sosial. Jurnal PKS Vol. 15 No. 1; pp. 18

Azwar, S. (2004). Pengantar psikologi intelegensi. Yogyakarta: Pustaka Pelajar.

Chodidjah, S, \& Kusumasari, A.P. (2018). Pengalaman ibu merawat anak usia sekolah dengan autis. Jurnal Keperawatan Indonesia. Vol 21 No. 2; pp. 94-100

Djatmika, Wibowo, A.H.,Sugini,Halim, H. \& Mohamad, B. Multimodal strategies in teaching children with autism: A discourse analysis. Sys Rev Pharm Vol 11(2). (2020). Page 219229.

Hikmawati, A., Djatmika, \& Sumarlam. (2019) Expressive skill of children with autism: A psycholinguistics study. Humanus. Vol 18(1). Pp. 101-113. 
Hirosawa T, Kontani K, Fukai M, Kameya M, Soma D, Hino S, et al. (2020) Different associations between intelligence and social cognition in children with and without autis, m spectrum disorders. PLOS ONE 15(8)

Hoerr, Thomas R. (2000). Multiple Intelligences. Terjemahan oleh Nilandari, Ary. 2007. Bandung: Penerbit Kaifa.

Ivony, T., \& Desmawati, L. (2018). Strategi pembelajaran anak autis di SLB Autisma Yogasmara, Semarang. E-Plus. Vol. 3, No. 1, pp. 17-24

Kover, S.T., Haebig, E., Oakes, A., McDuffie., Hagerman, R.J., \& Abbeduto, L. (2014). Comprehension in boys with autism spectrum disorders. Am J Speech Lang Pathol. Vol 23 (3): pp. 385-394

Krantz, P.J., Zalenski, S., Hall, J.H., Fenske, E.C., \& McClannahan, L.E. (1981). Teaching complex language to autistic children. Analysis and Intervention in Developmental Disabilities. Vol. 1, Issue 3-4: pp. 259-297

Maljaars, J., Noens, I., Scholte, E., \& Berckelaer-Onnes, I. (2012). Language in low-functioning children with autistic disorder: differences between receptive and expressive skills and concurrent predictors of language. Journal of Autism and Developmental Disorders Vol. 42:pp. 2181-2191

McConnel, S.A. (2010). Sentence complexity in children with autism and specific language impairment. Dissertation. University of lowa

Puspitaningtyas, A.R., \& Pratiwi, V. (2018). Pendekatan pembelajaran anak autis dengan menggunakan metode floor time di sekolah dasar Kecamatan Situbondo Kabupaten Situbondo. Jurnal Riset Pendidikan Dasar Vol. 02 (2): pp. 78-83

Rahayu, S.M. (2014). Deteksi dan intervensi dini pada anak autis. Jurnal Pendidikan Anak. Vol. 3. No. 1: pp. $420-428$

Safaria, T. (2005). Autisme: pemahaman baru untuk hidup bermakna bagi orang tua. Yogyakarta: Graha Ilmu.

Schuler, A.L. \& Fletcher, E.C. (2003). Making communication meaningful: cracking the language interaction code. In autism-from research to individualized practice .(ed. Gabriels, Robin, L and Hill, Dina, E). London: Jessica Kingsley Publishers.

Shulman, C. (2003). Bridging the process between diagnosis and treatment. In autism-from research to individualized practice .(ed. Gabriels, Robin, L and Hill, Dina, E). London: Jessica Kingsley Publishers.

Taryadi, \& Kurniawan, I. 2017. Pembelajaran anak autis dengan Picture Exchange Communication System (PECS) berbasis multimedia augmented reality. Dalam Seminar Nasional Informatika Medis (SNIMed) VIII; p. 29

Toth, K., Munson, J., Meltzoff, A.N., \& Dawson, G. (2006). Early predictors of communication development in young children with autism spectrum disorder: Joint attentio, imitation, and toy play. Journal of Autism and Development Disorders. Vol. 36; pp. 993-1005

Wenar, Charles. (2004). Developmental psychopathology: from infancy through adoleslence. New York: McGraw Hill. 